\title{
Autologous and homologous skin grafts treated with platelet-rich plasma (PRP): experimental study in rabbits ${ }^{1}$
}

\author{
Bernardo Kemper ${ }^{2}$, Cláudia V.S. Brandão ${ }^{2 *}$, Victor J.V. Rossetto ${ }^{2}$, \\ Lucas F.S. Gushiken ${ }^{3}$, Carlos R. Padovani ${ }^{3}$ and Claudia H. Pellizzon ${ }^{3}$
}

\begin{abstract}
Kemper B., Brandão C.V.S., Rossetto V.J.V., Gushiken L.F.S., Padovani C.R. \& Pellizzon C.H. 2018. Autologous and homologous skin grafts treated with platelet-rich plasma (PRP8): experimental study in rabbits. Pesquisa Veterinária Brasileira 38(9):1818-1823. Faculdade de Medicina Veterinária e Zootecnia, Rua Prof. Dr. Walter Mauricio Correa s/n, Cx. Postal 560, Distrito de Rubião Júnior, Botucatu, SP 18618-681, Brazil. E-mail: valeriasb@fmvz.unesp.br

The aim of the present study was to compare tissue repair of skin defects in rabbits submitted to autologous and homologous grafts treated or not with platelet-rich plasma (PRP). We selected nine rabbits and constituted four groups, designated as G1, in which were performed autologous graft treated with PRP; G2, autologous graft only; G3, homologous graft treated with PRP; and G4, homologous graft only. Macroscopic and histomorphometric evaluation was realized. The histomorphometric evaluation was performed by Hematoxylin/Eosin and Masson's Trichrome staining with quantification of collagen fibers, macrophages, fibroblasts and vessels. The autologous graft treated with PRP showed positive influence on the early stage of the tissue repair process at the macroscopic evaluation, characterized by rosy color and cosmetic appearance. At the histomorphometric evaluation, there was no statistical difference in the number of macrophages and fibroblasts between the treated grafts or not with the PRP, as well as the quantification of vessels and collagen fibers. It can be concluded that PRP promotes a positive influence on the initial phase or "take" of the graft.
\end{abstract}

INDEX TERMS: Skin grafts, platelet-rich plasma, rabbits, skin transplantation, wound healing, tissue repair, allografts, autografts, surgery.

\begin{abstract}
RESUMO.- [Enxertos cutâneos autólogos e homólogos tratados com plasma rico em plaquetas (PRP): estudo experimental em coelhos.] Objetiva-se com o presente estudo comparar a reparação tecidual de defeitos cutâneos em coelhos, submetidos a enxertos autólogos e homólogos, tratados ou não com plasma rico em plaquetas (PRP). Para isso, foram selecionados nove coelhos e constituídos quatro grupos experimentais, designados como G1, no qual foi realizado enxerto autólogo tratado com PRP; G2, enxerto autólogo; G3, enxerto homólogo tratado com PRP; e G4, enxerto homólogo. Foram realizadas avaliações macroscópica e histomorfométrica, por meio das colorações de Hematoxilina/Eosina e Tricômio de Masson, incluindo quantificação de fibras colágenas, contagem
\end{abstract}

\footnotetext{
${ }^{1}$ Received on August 29, 2017.

Accepted on September 13, 2017.

${ }^{2}$ Faculdade de Medicina Veterinária e Zootecnia (FMVZ), Universidade Estadual Paulista (Unesp), Rua Prof. Dr. Walter Mauricio Correa s/n, Cx. Postal 560, Distrito de Rubião Júnior, Botucatu, SP 18618-681, Brazil. *Corresponding author: valeriasb@fmvz.unesp.br

${ }^{3}$ Instituto de Biociências de Botucatu (IBB), Unesp, Rua Prof. Dr. Antônio Celso Wagner Zanin 250, Distrito de Rubião Júnior, Botucatu, SP 18618-689, Brazil.
}

de macrófagos, fibroblastos e vasos. 0 uso do enxerto autólogo com PRP influenciou positivamente na fase inicial do processo de reparação tecidual à avaliação macroscópica, caracterizada por coloração rósea e de aspecto cosmético. À avaliação histomorfométrica, não houve diferença estatística quanto ao número de macrófagos e fibroblastos entre os enxertos tratados ou não com o PRP, bem como quanto às contagens de vasos e a quantificação das fibras colágenas. Conclui-se que o PRP sob a promoveu influência positiva na fase inicial ou de "pega" do enxerto autólogo.

TERMOS DE INDEXAÇÃO: Enxertos cutâneos, enxerto de pele, cicatrização de feridas, reparação tecidual, aloenxertos, autoenxertos, coelhos, cirurgia.

\section{INTRODUCTION}

The repair of skin wounds should incorporate complex biological and molecular events that include cell migration, proliferation and differentiation, and angiogenesis (Martin 1997, Singer \& Clark 1999). 
Numerous efforts have been employed in order to promote such events with special focus on the use of growth factors, such as platelet-rich plasma (PRP) (Eppley et al. 2004).

The positive clinical results of PRP are based on the increased platelet concentration and growth factors, which promote the regulation of cell migration and cell proliferation and, consequently, accelerate the process of tissue repair (Crovetti et al. 2004, Freymiller \& Aghaloo 2004, Eppley et al. 2004, Roubelakis et al. 2014).

Despite the benefits of PRP in extensive skin lesions located at the ends or resulting from trauma, burns or following excision of tumors, the use of reconstructive surgery techniques is also necessary, such as free grafts (Swaim 2003, Fowler 2006, Pavletic 2011, Bohling \& Swaim 2012, MacPhail 2013). However, the repair of large cutaneous defects with free skin grafts can be associated to some complications, such as infection and seroma, which can delay or restrain the revascularization of the free skin graft, and consequently result in necrosis (Pavletic 2011). Thus, the PRP is a product with great potential to improve the integration of skin grafts (Vendramin et al. 2006, Almeida et al. 2008, Eppley et al. 2004).

Because of this, the aim of the present study is to compare the tissue repair of skin defects in rabbits submitted to autologous or homologous grafts, treated or not with PRP.

\section{MATERIALS AND METHODS}

Experimental design. Were utilized nine New Zealand Albino female rabbits (Oryctolagus cuniculus), aged between 300 days and 400 days, and with $3.0 \mathrm{~kg}$ to $4.0 \mathrm{~kg}$ of body weight (CEUA 192/2011).

After trichotomy and antisepsis with chlorhexidine $0.5 \%$ of the dorsum, each rabbit was subjected to four full thickness skin defects of $2,0 \times 2,0 \mathrm{~cm}$ in size and spaced of $1.5 \mathrm{~cm}$ apart (Fig.1). The cutaneous muscle of the trunk was preserved.

The detached skin segments of the right side were exchanged position in order to create two autologous grafts (Fig.1). For this, the cranial free skin grafts were destined to occlusion of the caudal defects and vice-versa. The cranial defects were treated with $0.5 \mathrm{ml}$ of PRP in liquid form, disposed on the wound bed, while the caudal defects were treated with $0.5 \mathrm{ml}$ lactated Ringer's solution.

Subsequently, the detached skin segments of the left side were exchanged between the rabbits in order to create two homologous grafts (Fig.1). Similarly, cranial grafts were treated with $0.5 \mathrm{ml}$ of PRP in liquid form, while the caudal grafts were treated with $0.5 \mathrm{ml}$ of lactated Ringer's solution. All vertices of the grafts were sutured with 5-0 monofilament nylon in a simple interrupted pattern. At the center of these grafts were realized two longitudinal incisions of $4 \mathrm{~mm}$ in length.

Thus, 36 skin lesions were allocated into four groups designed as G1, constituted by autologous grafts treated with PRP; G2, constituted by autologous grafts without treatment with PRP; G3, constituted by homologous grafts treated with PRP; and G4, constituted by homologous grafts without treatment with PRP (Fig.1).

PRP preparation. To obtain PRP were collected aseptically $10 \mathrm{ml}$ of blood from each rabbit through the cannulation of the central ear artery using a catheter $20 \mathrm{G}$. of these, $9 \mathrm{ml}$ of blood were distributed equally into two tubes containing sodium citrate $3.2 \%$, and $1 \mathrm{ml}$ destined for platelet count.

The first centrifugation was performed at $200 \mathrm{G}$ for 10 minutes in a centrifuge refrigerated at $22^{\circ} \mathrm{C}$ (Hermle Z326K, Hermle Labortechnik GmbH, Wehingen, Baden-Württemberg, Germany). After the first centrifugation, $50 \%$ of the supernatant was discarded and the remaining amount was placed in another tube for additional centrifugation at $400 \mathrm{G}$ for 10 minutes (Donatti et al. 2013). Finally, approximately two thirds of the supernatant was discarded and the remaining one third was homogenized and designated as PRP, consisting of minimum increase of four times and average final concentration of 1.511 .392 platelets (variation of 1.140 .210 to 2.247.850 platelets).

Anesthetic and postoperative protocols. For the surgical procedures, the animals were tranquilized with acepromazine (Acepran 0.2\%, Univet, São Paulo/SP, Brazil) and morphine (Ketamin-S, Cristália, Itapira/SP, Brazil), both intramuscularly at a dose of $0.5 \mathrm{mg} / \mathrm{kg}$, followed by dissociative anesthesia with ketamine (Ketamine, Vetnil, Louveira/SP, Brazil) and xylazine (Anasedan Pet, Ceva, Paulinia/SP, Brazil) intramuscularly, respectively, at doses of $25 \mathrm{mg} / \mathrm{kg}$ and $0.25 \mathrm{mg} / \mathrm{kg}$. For transoperative analgesia, animals received lidocaine (Xylestesin, Cristália, Itapira/SP, Brazil), ketamine and morphine as an in intravenous infusion, at a rate of $50 \mathrm{mcg} / \mathrm{kg} / \mathrm{min}, 5 \mathrm{mg} / \mathrm{kg} / \mathrm{h}$ and $0.1 \mathrm{mg} / \mathrm{kg} / \mathrm{h}$ respectively.

All animals received in the postoperative period penicillin $\mathrm{G}$ (Benzetacil, Eurofarma, Ribeirão Preto/SP, Brazil) intramuscularly at a dose of $40.000 \mathrm{IU} / \mathrm{kg}$, tramadol hydrochloride (Tramadol, Teuto, Anápolis/G0, Brazil) intramuscularly, at a dose of $2 \mathrm{mg} / \mathrm{kg}$, and meloxicam (Meloxicam, Eurofarma, Ribeirão Preto/SP, Brazil) subcutaneously, at a dose of $2 \mathrm{mg} / \mathrm{kg}$. The cleaning of the lesions was performed daily with sterile saline, and the area of the grafts coated with occlusive bandage Rayon (Curatec AGE 30 Rayon, São José dos Campos/SP, Brazil).

Macroscopic and histomorphometric evaluations. Macroscopic evaluation of skin grafts was performed at five, 12 and 19 days postoperatively, and documented by standardized photography in a controlled environment. The blind evaluation of photographic images was performed by the same examiner.

We evaluated by a score system the presence of secretions, skin color and the cosmetic appearance of the lesions. The secretion was classified as none (0); mild (1), moderate (2), and severe (3). The skin color was classified as rosy (1), purple (2) and dark (3)

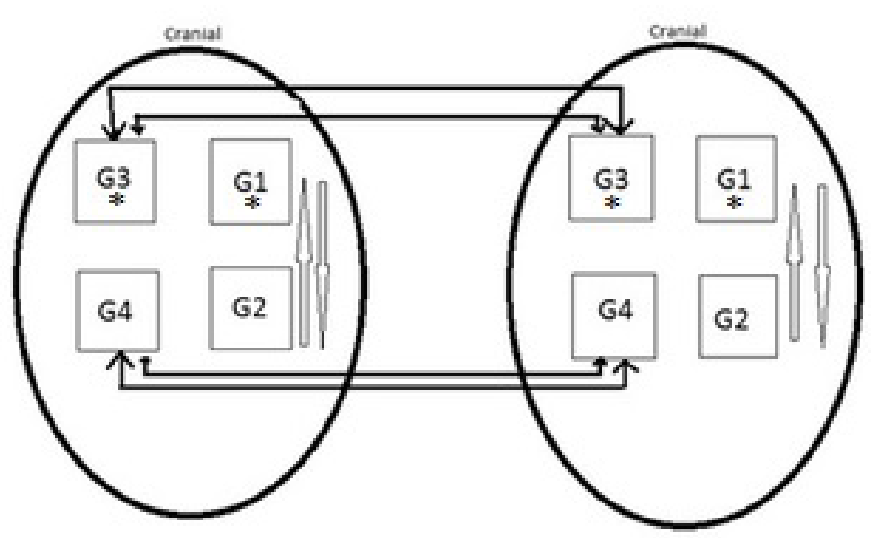

Fig.1. Schematic representation of the formation of the experimental groups. Note the transfer of the skin segments for preparation of the autologous grafts (light arrows) and homologous grafts (solid arrows). G1 = autologous grafts treated with the PRP, G2 = autologous grafts without treatment, G3 = homologous grafts treated with the PRP, G4 = homologous grafts without treatment. Note the asterisk $\left(^{*}\right)$ for the groups treated with PRP in liquid form. 
(Vendramin et al. 2010). The cosmetic appearance was classified as excellent (1) when the entire area of the graft was filled with healthy skin appearance, good (2) when up to $20 \%$ of the graft presented scabs formation, reasonable (3) when $20 \%$ to $80 \%$ of the graft was replaced by scabs, and poor (4) when more than $80 \%$ of the graft was replaced by scabs.

Additionally, superficial necrotic areas were measured using the Image ${ }^{\circledR}$ software (National Institutes of Health, Maryland, USA) by settings "Set Scale" and "Measure". The superficial necrotic areas were characterized by dark skin color and crust formation.

At the 19th postoperative days, full thickness fragments of the central area of each graft was collected using a punch of $0.8 \mathrm{~cm}$ diameter. The fragments were fixed in 10\% formalin for 48 hours, and routinely processed for histopathology evaluation. The samples were subjected to Hematoxylin and Eosin (HE) staining in order to evaluate the average number of fibroblasts, macrophages and vessels. For this evaluation, five photomicrographs were performed using a 100x objective lens with an optical microscope (Carl Zeiss Axio Lab A1, Jena, Germany), and a digital microscope Nikon Coolscope II (Nikon Coolscope II, Nikon Co, Japan). The photomicrographs were performed of each of the central region of the 36 grafts, totalizing 180 photomicrographs.

The samples were subjected to Masson's trichrome staining in order to evaluate the collagen tissue deposition. The quantification of collagen fibers was performed with AVSoft Bioview Spectra ${ }^{\circledR}$ software (Sandhill Scientific Co., Milwaukee, USA) from the average collagen area measurement $\left(\mu \mathrm{m}^{2}\right)$ based on the color difference. For this evaluation, five photomicrographs were performed using a 100x objective lens with an optical microscope (Carl Zeiss Axio Lab A1, Jena, Germany), and a digital microscope Nikon Coolscope II (Nikon Coolscope II, Nikon Co, Japan). The photomicrographs were performed of each of the central region of the 36 grafts, totalizing 180 photomicrographs.

Statistics. For macroscopic evaluation was applied Fisher's exact test. For evaluation of the average number of fibroblasts and macrophages was applied ANOVA followed by Tukey test. To evaluate the mean number of vessels and collagen fibers was applied ANOVA followed by Bonferroni and Bartlett tests. It was considered a statistical significance level of $\mathrm{p}<0.05$.

\section{RESULTS}

\section{Macroscopic evaluation}

Considering the presence of secretion, all animals showed serous secretion with no statistical difference between the treatments and among the moments of evaluation of each treatment.

Considering the skin color, at the $5^{\text {th }}$ day postoperatively was verified the prevalence of rosy color in the grafts of the G1 ( $p<0,05)$. There was no statistical difference among the moments of evaluation of each treatment. Despite this, the homologous skin grafts of the G3 and G4 presented dark color at the 19 th day postoperatively.

Similarly, when considering the cosmetic appearance of the lesions, the autologous skin grafts of the G1 and G2 showed superiority over the homologous skin grafts of the G3 and G4, characterized by good to excellent cosmetic appearance $(\mathrm{p}<0.05)$. There was no statistical difference among the moments of evaluation of each treatment.

Considering the digital measurement of the necrotic areas, there was no statistical difference between the treatments and among the moments of evaluation of each treatment. Despite this, the homologous skin grafts of the G3 and G4 presented the largest areas of necrosis at the 19th day postoperatively.

The macroscopic evaluation of the grafts at the established postoperative days is presented in Figure 2.

\section{Histomorphometric evaluation}

Considering the average number of vessels and the digital quantification of collagen fibers, there was no statistical difference between the treatments and among the moments of evaluation of each treatment (Fig.3).

The average number of macrophages at the 19th day postoperatively, however, was higher in the homologous skin grafts of the G3 and G4 compared to the autologous skin grafts of the G1 and G2 (p<0.01) (Fig.3). There was no statistical difference among the moments of evaluation of each treatment.

Opposite to macrophages count, the average number of fibroblasts was larger in autologous skin grafts of the G1 and G2 ( $\mathrm{p}=0.04)$ at the different moments of evaluation

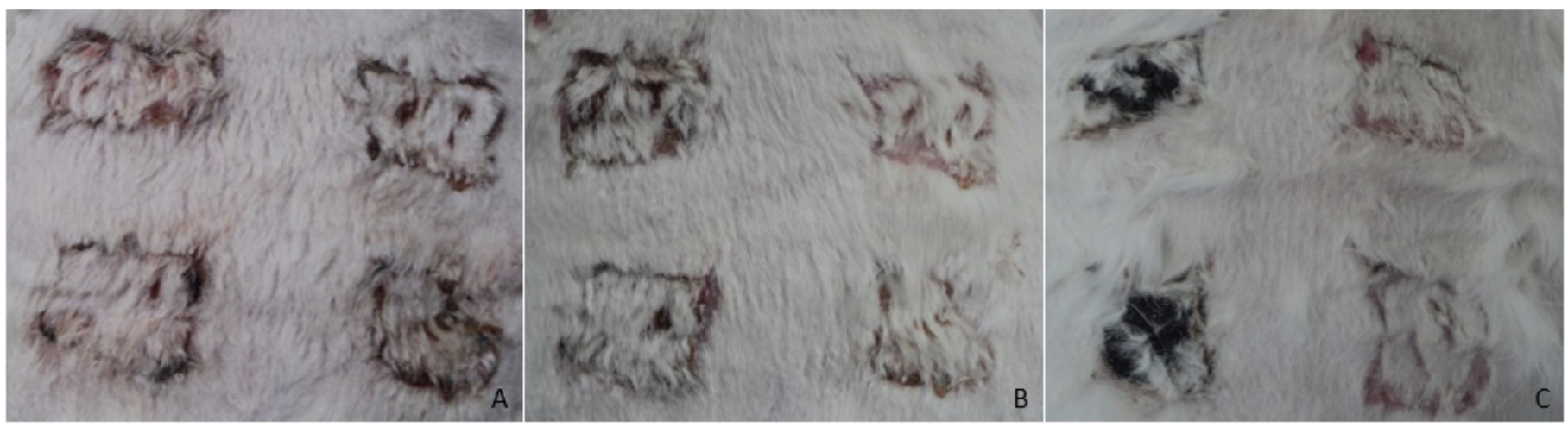

Fig.2. Macroscopic evaluation of the skin grafts performed in Rabbit 7. The autologous and homologous grafts are positioned, respectively, at the right and left side. The cranial defects were treated with PRP in liquid form. (A) Five days postoperatively. the prevalence of rosy color in the grafts. (B) 12 days postoperatively. Note the largest areas of necrosis of the homologous grafts. (C) 19 days postoperatively. Note the good cosmetic appearance of the autologous grafts. 

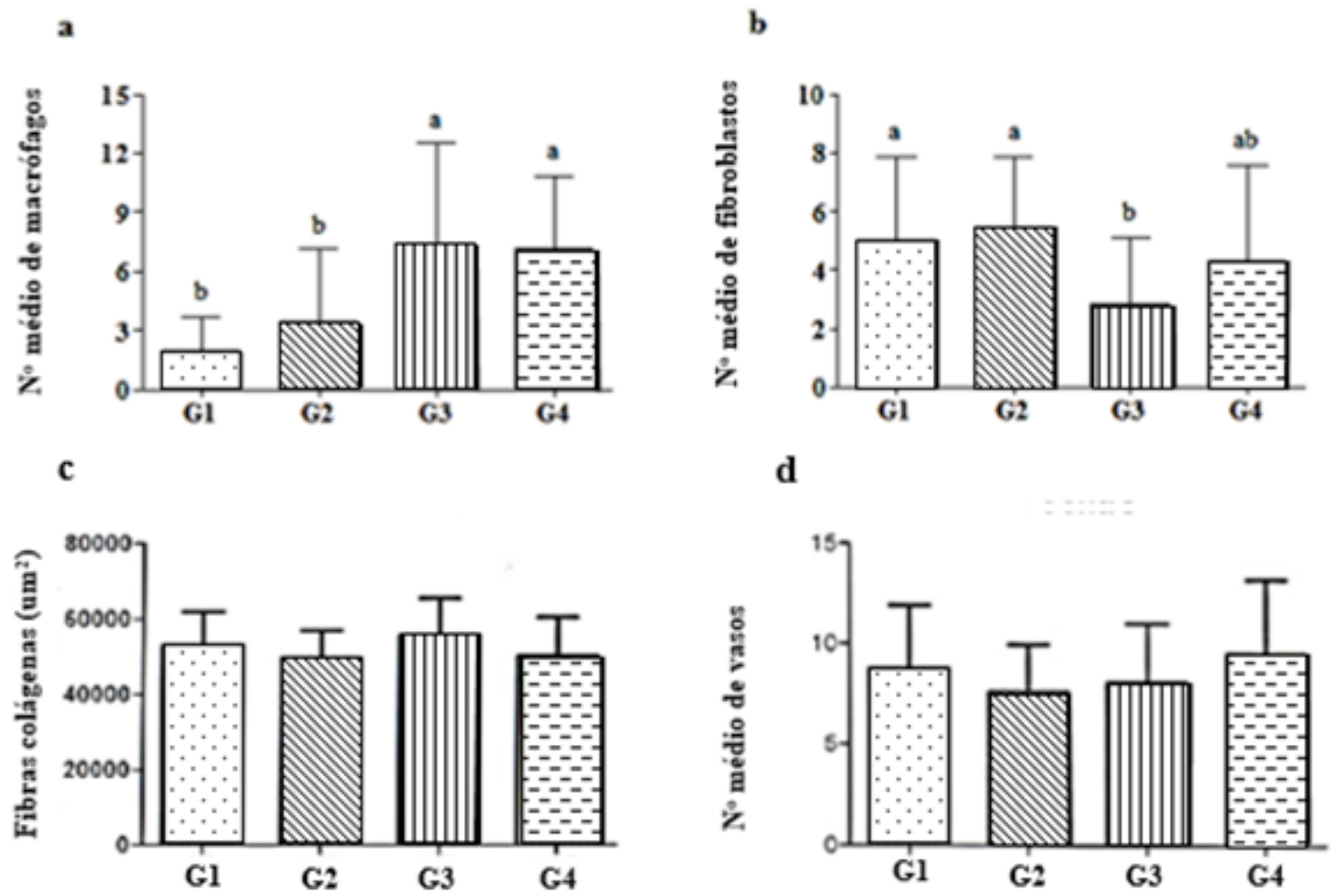

Fig.3. (A) Average value and standard deviation of macrophages, (B) fibroblasts, (C) collagen fibers, (D) vessels of the center of the skin grafts at day 19th. G1 = autologous graft treated with PRP, G2 = autologous graft without treatment, G3 = homologous graft treated with the PRP, G4 = homologous graft without treatment. Different letters denote statistical significance $(\mathrm{p}<0.05)$.

Table 1. Distribution of the average value and standard deviation of vessels, macrophages and fibroblasts, and the quantification of collagen fibers of the central areas of the autologous and homologous skin grafts

\begin{tabular}{|c|c|c|c|c|c|c|c|c|c|c|c|c|c|c|c|c|}
\hline $\begin{array}{l}\text { Rabbit } \\
\text { number }\end{array}$ & \multicolumn{4}{|c|}{$\begin{array}{l}\text { Average value and standard deviation } \\
\text { of vessels }\end{array}$} & \multicolumn{4}{|c|}{$\begin{array}{c}\text { Average value and standard } \\
\text { deviation of macrophages }\end{array}$} & \multicolumn{4}{|c|}{$\begin{array}{l}\text { Average value and standard } \\
\text { deviation of fibroblasts }\end{array}$} & \multicolumn{4}{|c|}{ Average amount $\left(\mu \mathrm{m}^{2}\right)$ of collagen fibers } \\
\hline 1 & $9 \pm 4$ & $19 \pm 12$ & $12 \pm 6$ & $20 \pm 7$ & $3 \pm 2$ & $6 \pm 4$ & $14 \pm 12$ & $5 \pm 0$ & $5 \pm 2$ & $9 \pm 2$ & $5 \pm 3$ & $4 \pm 4$ & 50798,91 & 44303,46 & 62402,31 & 54146,07 \\
\hline 3 & $19 \pm 9$ & $26 \pm 12$ & & & & & & & & & & & & & & \\
\hline 4 & $16 \pm 5$ & $14 \pm 4$ & $17 \pm 7$ & & $3 \pm 2$ & $4 \pm 4$ & & & & & & $9 \pm 1$ & & & & 3167 \\
\hline 7 & $7 \pm 4$ & $7 \pm 4$ & $6 \pm 5$ & & $1 \pm 1$ & $2 \pm 1$ & $9 \pm 3$ & $9 \pm 2$ & & & $1 \pm 2$ & $2 \pm 2$ & & & & 47529,66 \\
\hline 8 & $1 \pm 1$ & $6 \pm 3$ & $8 \pm 2$ & $6 \pm 3$ & $1 \pm 1$ & $1 \pm 1$ & $2 \pm 1$ & $9 \pm 2$ & $7 \pm 3$ & $4 \pm 2$ & $6 \pm 2$ & $0 \pm 1$ & 52963,74 & 45882,92 & 45541,02 & 45303,09 \\
\hline 9 & $8 \pm 3$ & $6 \pm 10$ & $13 \pm 7$ & $8 \pm 5$ & $4 \pm 1$ & $9 \pm 1$ & $6 \pm 3$ & $5 \pm 4$ & $1 \pm 0$ & $3 \pm 2$ & $2 \pm 1$ & $7 \pm 2$ & 58044,54 & 53630,35 & 53375,94 & 50912,39 \\
\hline
\end{tabular}

G1 = autologous grafts treated with the PRP, G2 = autologous grafts without treatment, G3 = homologous grafts treated with the PRP, G4 = homologous grafts without treatment.

(Fig.3). Additionally, when compared only the autologous grafts, treated or not with the PRP, there was no significant difference.

The distribution of the histomorphometric parameters evaluated in the central areas of the autologous and homologous skin grafts is presented in Table 1.

\section{DISCUSSION}

Apart from these findings, the autologous skin grafts treated with PRP showed prevalence of rosy color and good to excellent cosmetic appearance. These macroscopic findings indicate adequate revascularization of the skin grafts and positive 
influence of the PRP in the early stage of the tissue repair process (Fowler 2006, White 2009, Bohling \& Swaim 2012).

Excepting these findings, there was no other macroscopic evidence of the superiority of the skin grafts treated with the PRP compared to the untreated. At later stages, this could be justified by platelet inactivation in the recipient bed. The activation of the platelets is required to the release of growth factors, and it is dependent of the collagen and other substances generated by tissue trauma (Dionyssiou et al. 2013). In the present study, however, there was a contact of the PRP with the traumatized tissue, but probably insufficient to promote platelet activation. According to Vendramin et al. (2010), these tissue substances were not sufficient to activate platelets, which would necessitate prior activation to applying the PRP.

Considering the average number of vessels and the digital quantification of collagen fibers, there was no statistical difference between the treatments and among the moments of evaluation. Similar results were verified by Bauer et al. (2009), evaluating the PRP in the repair of skin wounds in rats, probably due to the single administration of the PRP in liquid form. Serial administration of the PRP in chronic wounds promoted angiogenesis and granulation tissue formation (Crovetti et al. 2004). The gel presentation would promote PRP adhesion to the wound bed and therefore the contact time with the tissue substances responsible to platelet activation (Crovetti et al. 2004, Dionyssiou et al. 2013).

The average number of macrophages was higher in homologous skin grafts. Macrophages have an important role in tissue debridement and are expected in larger quantities as greater the extent of tissue necrosis (Broughton et al. 2006), which corroborates to the macroscopic findings of the homologous skin grafts from G3 and G4. As described by Mathes et al. (2010), evaluating homologous skin grafts in dogs, this finding could be explained by cellular rejection, since the evaluated animals were not subjected to immunosuppression. In humans, the survival of the homologous grafts depends on chronic immunosuppression and/or additional local therapy that promote less tissue necrosis and best incorporation of the transplanted tissue (Lanzetta et al. 2007). In this study, however, the PRP did not provide less tissue necrosis and influenced the macrophages count in the homologous skin grafts.

In opposition to the macrophages count, the average number of fibroblasts was larger in autologous skin grafts from G1 and G2 at the different moments of evaluation, probably due to smaller amount of tissue necrosis (Crovetti et al. 2004, Broughton et al. 2006). Additionally, when compared only the autologous grafts, treated or not with the PRP, there was no significant difference. Vendramin et al. (2010), instead, describe a largest proliferation of fibroblasts in autologous skin grafts treated with PRP. It is suggested that the discrepancy between the studies is related to the lack of platelet activation of the PRP in a liquid form (Krasna et al. 2007, Eppley et al. 2004). In a study assessing the effect of PRP on cultured fibroblasts, the PRP gel combined with thrombin stimulated the proliferation of dermal fibroblasts (Krasna et al. 2007).

Similarly to the macroscopic evaluation, there was no evidence of the superiority of the skin grafts treated with the PRP also at the histomorphometric evaluation, both in the autologous and homologous skin grafts, probably due to the inactivation of platelets in the recipient bed (Dionyssiou et al. 2013).
According to studies, quantitative and qualitative changes in platelets could interfere with the regenerative potential of PRP (Messora et al. 2008, Vendramin et al. 2010).

Additionally, obtaining samples for histomorphometry only at the 19th day after grafting may have contributed to the lack of evidence of the beneficial effects of PRP. In a similar study in rats, PRP had a positive influence on the repair of skin wounds in the initial period of the tissue repair process, especially at the 3rd day, and whose influence has been gradually decreasing until the 14 th day postoperatively (Bauer et al. 2009).

\section{CONCLUSIONS}

Under the experimental conditions it can be concluded that the PRP in the liquid form may have positive influence in the early stages of the graft integration process.

Further studies should be considered to evaluate the prior activation of the PRP gel in order to enhance the positive influence of the PRP in the later stages of the tissue repair process.

Conflict of interest statement.- The authors have no competing interests.

\section{REFERENCES}

Almeida A.R.H., Menezes J.A., Araújo G.K.M. \& Correa A.V. 2008. Utilização de plasma rico em plaquetas, plasma pobre em plaquetas e enxerto de gordura em ritidoplastias: análise de casos clínicos. Revta Bras. Cir. Plast. 23(2):82-88

Bauer J.A., Correa L., Lima F.L.M., Lima L.A.P.A. \& Pustiglioni F.E. 2009. Efeitos do plasma rico em plaquetas no processo de reparação de feridas dérmicas padronizadas em ratos. Revta Periodontia 19(3):98-108.

Bohling M.W. \& Swaim S.F. 2012. Skin grafts, p.1271-1290. In: Tobias K.M. \& Johnston S.A. (Eds), Veterinary Surgery Small Animal. W.B. Saunders, St Louis.

Broughton 2nd G., Janis J.E. \& Attinger C.E. 2006. Wound healing: an overview. Plastic Reconstruct. Surg. 117(Suppl.7):1e-32. <http://dx.doi. org/10.1097/01.prs.0000222562.60260.f9> <PMid:16801750>

Crovetti G., Martinelli G., Issi M., Barone M., Guizzardi M., Campanati B., Moroni M. \& Carabelli A. 2004. Platelet gel for healing cutaneous chronic wounds. Transfus. Apheresis Sci. 30(2):145-151. <http://dx.doi.org/10.1016/j. transci.2004.01.004> <PMid:15062754>

Dionyssiou D., Demiri E., Foroglou P., Cheva A., Saratzis N., Aivazidis C. \& Karkavelas G. 2013. The effectiveness of intralesional injection of platelet-rich plasma in accelerating the healing of chronic ulcers: an experimental and clinical study. Int. Wound J. 10(4):397-406. <http:// dx.doi.org/10.1111/j.1742-481X.2012.00996.x> <PMid:22672105>

Donatti C., Brandão C.V.S., Ranzani J.J.T., Perches C.S., Padovani C.R., Pellizzon C.H. \& Sereno M.G. 2013. Uso do plasma rico em plaquetas no reparo de úlceras de córnea profundas induzidas em coelhos. Avaliação clínica e histomorfométrica. Arq. Bras. Med. Vet. Zootec. 65(3):809-818. <http:// dx.doi.org/10.1590/S0102-09352013000300029>

Eppley B.L., Woodell J.E. \& Higgins J. 2004. Platelet quantification and growth factor analysis from platelet-rich plasma: implications for wound healing. Plastic Reconstruct. Surg. 114(6):1502-1508. <http://dx.doi. org/10.1097/01.PRS.0000138251.07040.51>.

Fowler D. 2006. Distal limb and paw injuries. Vet. Clin. N. Am., Small Anim. Pract. 36(4):819-845. <http://dx.doi.org/10.1016/j.cvsm.2006.02.004> <PMid:16787789>

Freymiller E.G. \& Aghaloo T.L. 2004. Platelet-rich plama: ready or not? J. Oral Maxillofac. Surg. 62(4):484-488. <http://dx.doi.org/10.1016/j. joms.2003.08.021><PMid:15085518> 
Krasna M., Domanović D., Tomsic A., Svajger U. \& Jeras M. 2007. Platelet gel stimulates proliferation of human dermal fibroblasts in vitro. Acta Dermatovenerol. Alp. Pannonica Adriat. 16(3):105-110.<PMid:17994170>

Lanzetta M., Petruzzo P., Dubernard J.M., Margreiter R., Schuind F., Breidenbach W., Nolli R., Schneeberger S., Van Holder C., Gorantla V.S., Pei G., Zhao J. \& Zhang X. 2007. Second report (1998-2006) of the International Registry of Hand and Composite Tissue Transplantation. Transpl. Immunol. 18(1):16. <http://dx.doi.org/10.1016/j.trim.2007.03.002> <PMid:17584595>

Macphail C.M. 2013. Skin grafts, p.252-256. In: Fossum T.W., Dewey C.W., Horn C.V., Johnson A.L., MacPhail C.M., Radlinsky M.G., Schulz K.S. \& Willard M.D. (Eds), Small Animal Surgery. 4th ed. Mosby, St Louis.

Martin P. 1997. Wound healing-aiming for perfect skin regeneration. Science 276(5309):75-81. <http://dx.doi.org/10.1126/science.276.5309.75> <PMid:9082989>

Mathes D.W., Noland M., Graves S., Schlenker R., Miwongtum T. \& Storb R. 2010. A preclinical canine model for composite tissue transplantation. J. Reconstr. Microsurg. 26(3):201-207. <http://dx.doi.org/10.1055/s-0030-1247717> <PMid:20108180>

Messora M.R., Nagata M.J.H., Mariano R.C., Dornelles R.C., Bomfim S.R., Fucini S.E., Garcia V.G. \& Bosco A.F. 2008. Bone healing in critical-size defects treated with platelet-rich plasma: a histologic and histometric study in a rat calvaria. J. Periodont. Res. 43(2):217-223. <http://dx.doi. org/10.1111/j.1600-0765.2007.01017.x> <PMid:18302625>
Pavletic M.M. 2011. The skin, p.3-15. In: Pavletic M.M. (Ed.), Atlas of Small Animal Wound Management and Reconstructive Surgery. 3rd ed. W.B. Saunders, Philadelphia.

Roubelakis M.G., Trohatou O., Roubelakis A., Mili E., Kalaitzopoulos I., Papazoglou G., Pappa K.I. \& Anagnou N.P. 2014. Platelet-rich plasma (PRP) promotes fetal mesenchymal stem/stromal cell migration and wound healing process. Stem Cell Revs Reports 10(3):417-428. <http://dx.doi. org/10.1007/s12015-013-9494-8><PMid:24500853>

Singer A.J. \& Clark R.A. 1999. Cutaneous wound healing. New Engl. J. Med. 341(10):738-746. <http://dx.doi.org/10.1056/NEJM199909023411006> $<$ PMid:10471461>

Swaim S.F. 2003. Skin grafts, p.321-338. In: Slatter D.H. (Ed.), Textbook of Small Animal Surgery. 3rd ed. W.B, Saunders, Philadelphia.

Vendramin F.S., Franco D., Nogueira C.M., Pereira M.S. \& Franco T.R. 2006. Plasma rico em plaquetas e fatores de crescimento: técnica de preparo e utilização em cirurgia plástica. Revta Col. Bras. Cir. 33(1):24-28. <http:// dx.doi.org/10.1590/S0100-69912006000100007>

Vendramin S.P., Franco D., Schamall R.F. \& Franc T.R. 2010. Utilização do plasma rico em plaquetas (PRP) autólogo em enxertos cutâneos em coelhos Revta Bras. Cir. Plast. 25(1):4-10.

White R.A.S. 2009. Skin grafting, p.138-153. In: Williams J. \& Moores A. (Eds) Manual of Canine and Feline Wound Management and Reconstruction. 2nd ed. BSAVA, Shurdington. <http://dx.doi.org/10.22233/9781905319558.8> 